\title{
Assesment of Thyroid Function and Its Association with Free Thyroxin Hormone among Pregnant Women in Areas with Previous History Iodine Deficiency in Magelang, Indonesia
}

\author{
Donny Kristanto Mulyantoro, Ina KusRini, Taufik HidAYAT and Candra PusPitasari
}

Health Research and Development Magelang, Indonesia Ministry of Health, Magelang 56115, Indonesia

(Received June 28, 2019)

\begin{abstract}
Summary Iodine deficiency in pregnant woman can affect growth and development of fetus. People who live in an area that had affected by previous iodine deficiency may continuously affect by abnormal thyroid function. The aim of the study is to assess thyroid function, that was measured by the concentrations of thyroid stimulating hormone, and its relationships with free thyroxine (fT4) among pregnant women in the two different geographic areas with previous history of iodine deficiency in Magelang, Central Java, Indonesia. Cross-sectional study was conducted in two types of location (replete and non-replete area) in Magelang, Central Java, Indonesia. A total of 243 aged between 15-45 y old with no pregnancy complication from two different geographics areas of iodine replete and sufficient were include in study. Blood biochemical markers such as free thyroxine hormone and thyroid stimulating hormone were assessed by Elisa method. Median of fT4 in non-replete and replete area was $1.18(0.63-3.5) \mathrm{ng} / \mathrm{dL} ; 1.12(0.37-1.95) \mathrm{ng} / \mathrm{dL}$, respectively. Whilst, median of TSH in replete area was $1.27(0.09-8.21) \mathrm{ng} / \mathrm{dL}$ and non replete area was 1.3 (0.01-8.67) ng/dL. Correlation between fT4 and TSH showed significat relationship in non-replete area, $r=-0.39(<0.05)$, but it was not significant in replete area, $r=-0.08$ $(>0.05)$. In addition, scatter plot showed the relationship between fT4 and TSH levels pattern in the replete area more widespread. Pregnant womens who live in areas that had affected severe iodine deficiency intake may have abnormal thyroid function but it still euthyroid maintain by adequate iodine intake.
\end{abstract}

Key Words thyroid hormone, function, iodine.

Iodine deficiency has a negative effect on growth, development in early life and thyroid disorder in adults $(1,2)$. Long-term thyroid function of subjects with iodine deficiency and excess iodine during childhood tend to be abnormal although their current iodine intake is optimal (3). A small increase of iodine intake in the population that had affected by previous iodine deficiency could get an failure-response as thyroid function adaption, therefore it might induce abnormalities of thyroid hormone. Moreover, epidemiological studies should be considered not only presenting the intake, but also the history of intake of iodine population (2).

Indonesia is an area that has a previous history of the severe endemic of iodine deficiency disorder (IDD). The survey of thyroid enlargement in school children in 26 provinces in 1980 showed that $68 \%$ of the districts had a prevalence of Total Goitre Rate (TGR) of $>10 \%$. $40 \%$ of the sub-districts have the prevalence of TGR $>30 \%$ and in certain villages TGR school children reach $>80 \%$. Approximately 35 million people live in the endemic area of IDD (4).

Iodine deficiency disorder prevention programme are conducted with injections or capsules of iodine oil and the use of iodine salts ( $\geq 30 \mathrm{ppm} \mathrm{KIO}_{3}$ ) for household

E-mail: donny.kristanto@yahoo.com consumption (5) national surveys in 2003 showed that there has been a decline in TGR school children to $11.1 \%(6,7)$. The latest National Basic Health Survey on 2013 shows that all age groups are within normal limits and the levels of median iodine urine concentration in pregnant women was $169 \mu \mathrm{g} / \mathrm{L}(8)$.

Pregnant woment are susceptible group to get more health disorders during their pregnancy. The normal of thyroid function is important to achieve a healthy pregnancy that will ensure the fetus grows and develops optimally $(1,9,10)$. Therefore, the study to assess thyroid function, among pregnant women in the two different geographic areas that had affected by previous history of iodine deficiency is important to formulate IDD prevention program and policy.

\section{MATERIALS AND METHODS}

Subject and methods. Cross-sectional studies was conducted on pregnant mothers living in two different geographic areas with previous history of iodine deficiency Magelang Regency, Central Java province, Indonesia. Criteria of history iodine deficiency based on goiter status in early study in 1980, wherease it was known as severely endemic iodine deficiency and sufficient iodine intake area. The number of samples is 243 pregnant mothers consisting of 123 pregnant mothers 

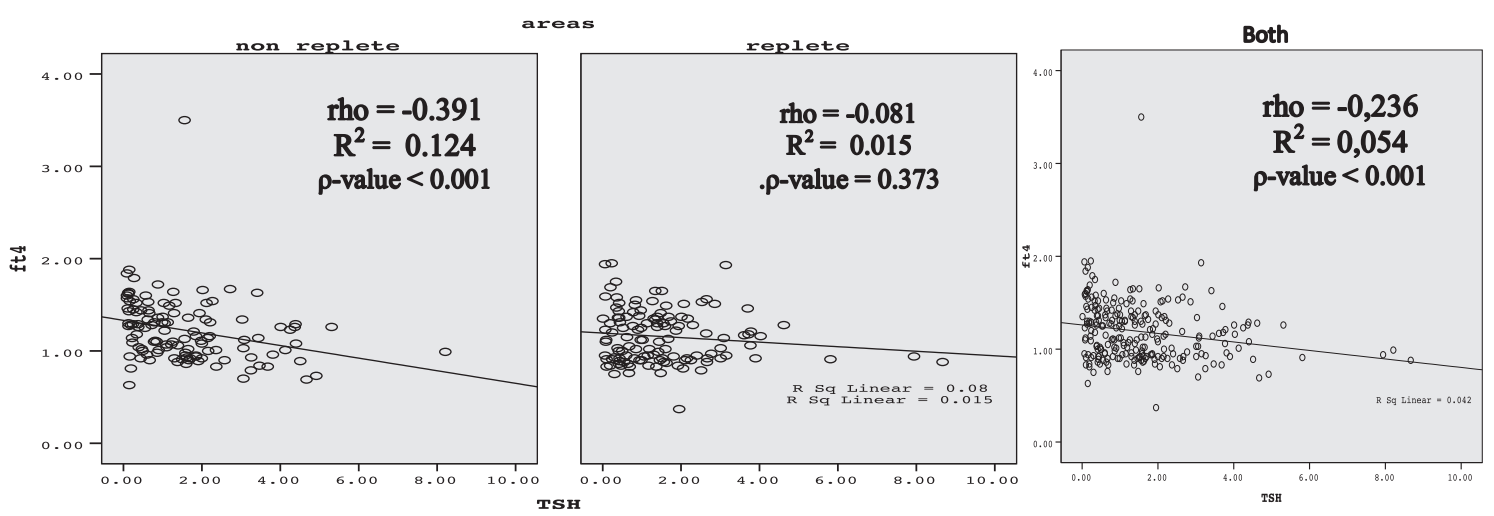

Fig. 1. Scatter plot curve between fT4 with TSH in an area with a previous history of the intake of iodine (replete) and adequate intake area of iodine.

of replete area and 120 pregnant mothers of non replete area. A number of minimal sample size uses a large formula of sample estimate proportions with absolute precision for the sample stratification of the trimester period of pregnancy (11). Samples were taken in a simple random sampling from the list of a pregnant women sampling frame that was obtained in each area. First, we take the list of pregnant women as sampling frame in each trimester in both area, then we select subject by simple random sampling from the frame list. Inclusion criteria, participants never get high doses of iodine capsules over the last five years and exclusion criteria, participants do not suffer from chronic pain and pregnancy complications. This research has received ethical approval from the Ethics commission of the Agency of the Litbangkes RI with numbers LB. 02.01/5.2/KE. 340/2015 and licensing from local service (12).

Assessment of thyroid function. Normal thyroid function is required to regulate the whole metabolism process in human which it is measured by blood biochemical markers of TSH and fT4 levels. It was taken by collected serum in pregnant women and measure of value using laboratories method by the principle of enzyme Immuno assay (ELISA), using reagents from Human 2004. Normal reference range fT4 following normal values for pregnant women in Human reagent's manual standart $0.8-2.2 \mu \mathrm{g} / \mathrm{L}$ (13) and the normal range of TSH using American Thyroid Association (ATA standart) for pregnant women, 1st trimester: $0.1-2.5 \mu \mathrm{g} / \mathrm{L}$; 2nd trimester: $0.2-3.5 \mu \mathrm{g} / \mathrm{L}$ and 3rd trimester: $0.3-$ $3.5 \mu \mathrm{g} / \mathrm{L}(14)$.

The iodine status is obtained by collecting urine for $3 \times 24 \mathrm{~h}$ on the day of the week, Monday and Wednesday. Urine samples were measured using a spectrofotmetry method, pregnant women with UIE levels of $<150 \mathrm{ug} / \mathrm{L}$ categorized iodium deficiency. Levels of iodine in the salt of household consumption are collected by taking the example of salt used for consumption in the home of pregnant women as much as $\pm 30 \mathrm{~g}$. The examination of iodine in salt is done by iodometric methods. The iodium in the water is obtained from a sample of water samples on the water source both groundwater and surface water, sufficiency samples assessed by viewing the representation of each water source at each research site, so that the 71 water intake point is obtained. Water samples were analyzed by spectrophotometry methods.

Statistical analysis. Univariate data analysis was executed to see data normality, data spread, standard deviation from subject characteristics and main variables. Analysis of Bivariate statistics was carried out considering the normality of the data. To see the mean difference between two areas of the main variables using independent $t$-test for data with normal distribution or Mann-Whitney U for data that have not a normal distribution, through Kolmogorov Smirnov test of normality.

Analysis of the relationship between fT4 and TSH conducted a test Correlations Spearman (Spearman's rho) for the nonparametric test to data that has not a normal distribution. Data analysis was performed using SPSS 21.

\section{RESULTS}

A total of 243 pregnant mothers participated in the study consisting of 123 pregnant women from the replete area and 120 pregnant women from non-replete areas. The main finding of the present study has shown in Fig. 1 whereas the relationship between fT4 and TSH serum levels have shown statistically significant in the non-replete area but it has not shown in the replete area. The scatter plot between TSH and fT4 in replete area more spread and unclear pattern of correlation. However, the value of both biochemical thyroid function markers showed similar results and has not shown the mean difference in both areas (Table 1).

Biochemical iodine markers that were measured by iodine urine concentration in two different geographical areas also showed similar results and not differ statistically. Iodine resource was identified as area iodine in drinking water and iodine in salts. The water iodine levels used for household consumption needs in nonreplete areas are higher with considerable differences. However, the levels of iodine in the iodine salts used for the consumption of pregnant mothers in statistically do not differ significantly ( \pm 40 ppm KIO3). 
Table 1. Iodine status and Thyroid function of pregnant women in the Replete and Non Replete areas.

\begin{tabular}{|c|c|c|c|}
\hline & Iodine Replete Area & Non-iodine Replate Area & Total combined areas \\
\hline \multicolumn{4}{|l|}{ General characteristics } \\
\hline Age $(y)^{*}$ & $28.1 \pm 6.2$ & $28.9 \pm 5.7$ & $28.5 \pm 5.9$ \\
\hline Pregnancy age $(\mathrm{wk})^{* *}$ & $20.3 \pm 8.8$ & $20.1 \pm 8.6$ & $20.2 \pm 8.7$ \\
\hline \multicolumn{4}{|l|}{ House iodine status } \\
\hline Iodine in water $(\mu \mathrm{g} / \mathrm{L})$ & $9.03 \pm 15.8$ & $19.85 \pm 14.3$ & \\
\hline Iodine in salt $\left(\mathrm{ppm} \mathrm{KIO}_{3}\right)^{*}$ & $40.7 \pm 21.12$ & $40.36 \pm 20.24$ & $40.53 \pm 20.62$ \\
\hline \multicolumn{4}{|l|}{ Biochemical iodine markers } \\
\hline $\begin{array}{l}\text { UIE } 3 \times 24 \mathrm{~h}(\mu \mathrm{g} / \mathrm{L}) 24 \mathrm{~h} \text { urinary iodine } \\
\text { excretion }(\mathrm{UIE})\end{array}$ & 222.67 & 250.67 & 231.00 \\
\hline Median (min-max) & $(63.67-626.00)$ & $(77.67-539.00)$ & $(63.67-626.00)$ \\
\hline \multicolumn{4}{|l|}{ Biochemical thyroid markers } \\
\hline $\mathrm{TSH}(\mathrm{ng} / \mathrm{dL})^{* *}$ & $1.54 \pm 1.43$ & $1.59 \pm 1.44$ & $1.57 \pm 1.43$ \\
\hline $\mathrm{fT} 4(\mathrm{ng} / \mathrm{dL})^{* *}$ & $1.16 \pm 0.29$ & $1.22 \pm 0.35$ & $1.19 \pm 0.32$ \\
\hline \multicolumn{4}{|l|}{ Thyroid Function Status } \\
\hline - Subclinical hyperthyroidism & 7.3 & 5.8 & 74.6 \\
\hline - Secondary hyperthyroidism & 0.0 & 1.6 & 6.6 \\
\hline - Hypothyroxinemia & 4.1 & 0.0 & 0.8 \\
\hline - Subclinical hypothyroidism & 13.8 & 14.9 & 2.1 \\
\hline - overt hypothyroidism & 0.0 & 3.3 & 14.3 \\
\hline
\end{tabular}

\footnotetext{
* Independent $t$-test replate and non replate.

** Mann-Whitney U replate and non replate.
}

Table 1 shows the status of the thyroid function of pregnant women in both types of research areas. The percentage of hypothyroid subclinics and hyperthyroid subclinics in the replete area is higher than in nonreplete areas. Correlations Spearman's test results generally demonstrate a meaningful relationship between fT4 and TSH (Table 1). But when done stratification based on the type of area with a history of deficiency of heavy iodine intake in the past (replete) and the area of adequate intake of non-replete iodine), it appears that there is no meaningful relationship between fT4 with TSH in the area Replete $(p>0.05)$. Conversely, in nonreplete areas there are inverse correlation $(<0.001)$ between fT4 and TSH which means that the lower the hormone levels of free thyroxine (fT4) then the higher hormone levels of TSH.

\section{DISCUSSION}

The iodine deficiency in early life will adversely affect the growth and development of the fetus especially the development of the brain (16-18). Therefore, pregnant women and fetuses are periods in the life cycle of the most vulnerable human beings experiencing iodine deficiency due to an increased need for iodine during pregnancy $(1,18,19)$. Since lipiodol injection and iodine supplementation capsule was discontinued, respectively in 2001 and 2009 (15-17) the iodine salt is the main strategy to provide iodine requirement in the population $(1,20)$.

The present study explain the tendency of abnormalities of thyroid hormone that was showed by difference pattern correlation between TSH and fT4. Moreover it was marked by pattern correlation more diffuse among pregnant women in an area that previously affected severe iodine deficiency. Its means the decline of fT4 is not necessarily followed by the increase of TSH. This may indicate an abnormality of thyroid function when fT4-TSH feedback mechanism does not run normally. Despite the based characteristic and iodine salt intake in two areas are similar, it means that the character is not a potential confounding variable that can interfere relationship between the fT4 and TSH hormones.

Thyroid function that was assessed by measuring the free Thyroxyn (fT4) and thyroid-stimulating hormone (TSH) levels have a strong correlation. Because of physiological metabolism in humans, there is a feedback mechanism between fT4 and TSH. Low levels of thyroid hormones will stimulate the pituitary to produce TSH (thyrotropin) hormones. Furthermore, increase of thyrotropin hormone will stimulate the thyroid gland to produce the thyroid hormone that will be released in the blood (circulation) $(2,22,23)$. But the evidence in this study showed decrease of stimulation on thyroid hormone feedback mechanism in area that had affected previous history severe iodine deficiency (replete area) in some pregnant women.

In populations with moderate to severe iodine deficiency, serum TSH concentrations are often slightly increased while $\mathrm{T}_{4}$ remains normal, and many people experience subclinical hypothyroidism. When iodine deficiency becomes more severe, TSH may increase further while the $\mathrm{T}_{3}$ slightly increased or remains unchanged and $\mathrm{T}_{4}$ decreases. The serum concentration of TSH is usually reversed with $\mathrm{T}_{4}$, but not with $\mathrm{T}_{3}$. If the iodine of the thyroid is depleted, the average concentration of $\mathrm{T}_{4}$ and $\mathrm{T}_{3}$ decreases, the concentration of TSH increases, and there is an increase in hypothyroidism in the population (2). 
In areas with a history of iodine intake deficiency, a long population exposed to the deficiency of iodine tends to have abnormal thyroid function in adulthood although the need for iodine is already adequate. $(2,3$, 24) The minor increases in iodine intake in an area with previously deficient populations can alter thyroid disease patterns. The number of individuals with enlarged thyroid gland diffuse and partially developed into nodular goiter in areas of mild iodine deficiency often to found. These induced a lower average TSH concentration than a sufficient population due to the increase in the prevalence of thyroid nodularity and the multinodular toxins $(2,24-27)$.

Studies that was conducted in Denmark, Canada and Zimbabwe reported the incidence of thyroid function abnormalities following the administration of iodine in the previously deficient area of iodine and many cases of hyperthyroidism in the incidence of toxic mumps multinodular $(24,25,27)$ observations in Kivu, Zaire, in the previous area of moderate iodine deficiency and severe found thyrotoxicosis in individuals suffering from goiter after administration of the myphilic salts of iodine (148 ppm iodine). (28) UK Research Reports The incidence of the negative antibody thyrotoxicosis is closely correlated with the earlier endemic goitres prevalence in the towns $(R=0.9)$ indicating the current high toxic nodular mumps in cities that were previously endemic to the Hyacinth region (26).

Iodine supplementation in Turkey succeeded in eliminating iodine deficiency in the eastern Black Sea region but was accompanied by an increase in the prevalence of autoimmune thyroiditis and thyroid dysfunction. The prevalence of hyperthyroidism (overt or subclinical) is more commonly found in moderately iodine regions than in mild iodine deficiency areas (3.6\% vs $0.7 \%)$, but the prevalence of hypothyroidism is no different between regions $(1.8 \%$ vs $1.4 \%)$ (29). The additions $250 \mu \mathrm{g}$ iodine to patient who living in a mild iodine deficiency area, a slight change in thyroid hormone function in the individual has a tendency of abnormality (30).

Although in small prevalence, cases of hypothyroxinemia and subclinical hyperthyroidism are more found in the replete area, in otherwise subclinical hypothyroidism was obtained in the non-replete area, overt hypothyroidism is precisely more found in non replete areas (12). This phenomenon cannot be explained completely due to data limitations including autoimunne thryoditis.

\section{CONCLUSION}

Pregnant womens who live in areas that had affected previous history of deficiency of iodine intake (replete) may have abnormal thyroid function because of decrease of stimulation feedback mechanism between fT4 and TSH. The state of the euthyroid pregnant womens can still be maintained by adequate iodine intake to pregnant woman through iodized salt. Monitoring of thyroid function of pregnant women needs to be done through health care efforts for treatment.

\section{Disclosure of state of COI}

All authors declare that they have no competing interests to declare.

\section{Acknowlegments}

The authors wish to thank to National Institute of Health Research and Development, Ministry of Health that supported this study.

\section{REFERENCES}

1) [WHO $]$ World Health Organization. 2007. Assessment of iodine deficiency disorders and monitoring their elimination, A guide for programme managers. Third edition, 2007.

2) Zimmermann MB, Boelaert K. 2015. Iodine deficiency and thyroid disorders. Lancet Diabetes Endocrinol 3(4): 286-295.

3) Chung HR. 2014. Iodine and thyroid function. Ann Pediatr Endocrinol Metab 19: 8-12.

4) Djokomoeljanto R, Satoto, Untoro R. 2004. IDD Control in Indonesia, in Towards the Global Elimination of Brain Damage Due tolodine Deficiency A global program for human development with a model applicable to a variety of health, social and environmental problems, Dr Basil S Hetzel, Oxford University Press, Delhi.

5) Mulyantoro DK. 2017. Iodine Supplementation for Pregnant Woman: Is It Necessary?. Indonesian Journal of Micronutrient 8(2): 137-150.

6) Directorat of Community Nutrition, Directorat General of Community Health, Ministry of Health. 2003. Technical Assistance for Evaluation on Intensified Iodine Deficiency Control Project. Final Report.

7) Mulyantoro DK. 2018. Gangguan Akibat Kekurangan Iodium (IDD), Ancaman Bencana Kemanusiaan yang Tidak Disadari, dalam Peran Serta Masyarakat dalam Penanggulangan IDD. Pustaka Pelajar Press, Yogyakarta, Indonesia (In Indonesian).

8) Kartono D, Atmarita, Jahari AB, Sukirman, Izwardy D. 2016. The situation Urinary Iodine Concentration (UIC) among school age children, women at reproductive age and pregnant women in Indonesia: the Analysis of Riskesdas 2013. Journal of the Indonesian Nutrition Association 39(1): 49-58 (In Indonesian).

9) Zimmermann MB. 2012. The Effects of Iodine Deficiency in pregnancy and infancy. Paediatr Perinat Epidemiol 26(1): 108-117.

10) Qian M, Wang D, Watkins WE, Gebski V, Yan YQ, Li M, Chen ZP. 2005. The effects of iodine on intelligence in children: a metaanalysis of studies conducted in China. Asia Pac J Clin Nutr 14(1): 32-42.

11) Lemeshow S, Hosmer Jr DW, Klar J. 1990. Adecuacy of Sample Size in Health Studies. John Wiley \& Son, Geneva.

12) Kusrini I, Mulyantoro DK, Sukandar PB, Budiman B. 2016. Maternal hypothyroidism during pregnancy in the goiter replete and non-replete area in Magelang District. Jurnal Kesehatan Reproduksi 7(1): 49-59 (In Indonesian).

13) Human. 2004. ELISA Test for the Quantitative Determination of TSH and FT4 in Human Serum. Human Gesellschaft fur Biochemica und Diagnostica mbH, Max-Planck-Rink 21-D-65205 Wiesbaden-Germany.

14) Teng W, Shan Z, Patil-sisodia K, Cooper DS. 2013. Hypothyroidism in pregnancy. Lancet Diabetes Endocrinol 1(3): 
228-237.

15) Dinas Kesehatan Kabupaten Magelang. 2004. Laporan Evaluasi Penanggulangan GAKY di daerah Endemis Kabupaten Magelang (Unpublished report:in Indonesian).

16) Pearce EN, Lazarus JH, Reyes RM, Zimmermann MB. 2016. Consequences of iodine deficiency and excess in pregnant women: an overview of current knowns and unknowns. Am J Clin Nutr 104: 918S-923S.

17) DeLong GR, Robbins J, Condliffe PG. 1989. Iodine and the Brain. Plenum Press. New York.

18) Hetzel BS. 1983. Iodine Deficiency Disorders (IDD) and Their Eradication. Lancet 2: 1126-1129.

19) Farebrother J, Naude CE, Nicol L, Sang Z, Yang Z, Jooste PL, Andersson M, Zimmermann MB. 2018. Effects of iodized salt and iodine supplements on prenatal and postnatal growth: A systematic review. Adv Nutr 9: 219-237.

20) Pandav CS, Yadav K, Srivastava R, Pandav R, Karmarkar MG. 2013. Iodine deficiency disorders (IDD) control in India. Indian J Med Res 138: 418-433.

21) Mulyantoro DK, Hakimi M, Basuki E. 2013. Relationship between iodine level of iodized salt in the household with iodine allowance based on Urinary Excretion of Iodine (UEI) value childbearing age women. Indonesian Journal of Micronutrient 5(1): 41-52 (in Indonesian).

22) Gardner DG, Shoback D. 2011. Greenspan's Basic \& Clinical Endocrinology, Ninth Edition. McGraw-Hill.

23) Pearce EN. 2017. Iodine Deficiency Disorders and Their Elimination. Springer.

24) Laurberg P, Pedersen KM, Vestergaard H, Sigurdsson G.
1991. High incidence of multinodular toxic goitre in the elderly population in a low iodine intake area vs high incidence of Graves' disease in the young in a high iodine intake area: comparative surveys of hyrotoxicosis epidemiology in East-Jutland Denmark and Iceland. J Intern Med 229: 415-420.

25) Williams I, Ankrett VO, Lazarus JH, Volpe R. 1983. Aetiology of hyperthyroidism in Canada and Wales. J Epidemiol Commun Health 37: 245-248.

26) Phillips DIW, Barker DJP, Smith BR, Didcote S, Morgan D. 1985. The geographical distribution of thyrotoxicosis in England according to the presence or absence of TSH-receptor antibodies. Clin Endocrinol 23: 283-287.

27) Todd CH, Allain T, Gomo ZAR, Hasler JA, Ndiweni M, Oken E. 1985. Increase in thyrotoxicosis associated with iodine supplements in Zimbabwe. Lancet 346: 1563-1564.

28) Bourdoux PP, Ermans AM, Mukalay wa Mukalay A, Filleti S, Vigner R. 1996. Iodine-induced thyrotoxicisis in Kivu, Zaire. Lancet 347: 552-553.

29) Emral R, Baştemir M, Erdoğan G, Güllü S. 2006. High prevalence of thyroid dysfunction and autoimmune thyroiditis in adolescents after elimination of iodine deficiency in Eastern Black Sea Region of Turkey. Turkish Journal of Endocrinology and Metabolism 1: 13-20.

30) Reinhardt W, Luster M, Rudorff KH, Heckmann C, Petrasch S, Lederbogen S, Haase R, Saller B, Reiners C, Reinwein D, Mann K. 1998. Effect of small doses of iodine on thyroid function in patients with Hashimoto's thyroiditis residing in an area of mild iodine deficiency. Eur J Endocrinol 139: 23-28. 